Volume and Issues Obtainable at Center for Sustainability Research and
Consultancywww.globalcsrc.org

\title{
Influence of Supply Chain Linkages with BoP Enterprises on Market Knowledge Competence and Propensity to Internationalization of MNEs: A Measurement Model
}

\author{
${ }^{1}$ Sulaman Hafeez Siddiqui, ${ }^{2}$ Ismail Bin Lebai Othman \\ ${ }^{1}$ Department of Management Sciences, TheIslamia University of Bahawalpur Pakistan. \\ Sulman.siddiqui@iub.edu.pk \\ ${ }^{2}$ School of Business Management, Universiti Utara Malaysia.i.othman@uum.edu.my
}

\begin{tabular}{l}
\hline ARTICLEDETAILS \\
\hline History \\
Revised format: Nov 2016 \\
AvailableOnline: Dec 2016 \\
\\
\hline Keywords \\
MNEs internationalization, \\
network theory, sustainable \\
supply chain, Base of Pyramid \\
enterprises, market knowledge \\
competence
\end{tabular}

JEL Classification:

Q01, C79

\begin{abstract}
Objectives: There has been growing interest in network theory of internationalization as a means to achieve 'cooperative advantage' and 'economies of networking'. Yet there is seldom any measurement model that may offer quantitative approach and tools to analyze role of supply chain linkages of Base of Pyramid (BoP) enterprises with MNE subsidiaries in host markets.

Design/Methods: The study makes use of statistical data reduction techniques such as factor analysis to test reliability and validity of the proposed model using data obtained through a structured questionnaire from supply chain/marketing managers of MNEs with backward and/forward supply chain linkages with BoP firms in Pakistan

Results: The study develops a measurement framework and structured questionnaire to analyze impact of sustainable/inclusive supply chain linkages as exogenous variable with the variables of subsidiary internationalization in host markets.

Implications/originality/value: The study offers implications for linking vast sector of micro and small enterprises with value chain network as economic agents of MNEs to support its innovation and market outreach strategy in a sustainable manner. Further empirical studies are needed to validate and extend the hypothesized relationships of proposed model of sustainable internationalization.
\end{abstract}

(C) 2016 The authors, under a Creative Commons Attribution-

NonCommercial 4.0

Corresponding author's email address: sulman.siddiqui@iub.edu.pk

Recommended citation:Siddiqui, S., \& Othman, I. (2016). Influence of Supply Chain Linkages with BoP Enterprises on Market Knowledge Competence and Propensity to Internationalization of MNEs: A Measurement Model.Journal of Business And Social Review In Emerging Economies, 2(2), 189-196. DOI:https://doi.org/10.26710/jbsee.v2i2.110 


\section{Introduction}

Concept and application of the Base of Pyramid (BoP hereafter) market initiated by Parhalad and Hart (2002) is under transition from potential consumer market (i.e. BoP 1.0) to producer-view of the poor communities in developing markets (i.e. BoP 2.0). However, the concept of the poor to be business partners or entrepreneurs was being initiated by Hernando De Soto in 2000 before Prahalad's contribution (Kolk et al., 2014). Multinational Enterprises (MNEs) are increasingly interested in engaging with BoP clusters as part of their global supply chain networks in their pursuit of sustainable competitiveness and internationalization. Yet much less economic or business rationale than the philanthropic one is available to managers in MNEs for engaging BoP suppliers and resellers in their supply chain networks.

Sustainability of economic systems and businesses models is gaining importance in academic research, public policy and business strategies (Sinkovics, Sinkovics\&Yamin, 2014; Soete, 2014; Chataway, Hanlin\&Kaplinsky, 2014; Oosterlaken, 2009). Emerging and developing economies are interested in promotion of inclusive entrepreneurship and inclusive entrepreneurship to alleviate poverty through market based economic policies. Emerging literature on Base of Pyramid (BoP) explains this new role of MNEs to partner poor communities in their supply chain network. Competitiveness of firm sector in the wake of globalization is also witnessing greater policy focus in developing and developed economies. MNEs are the focus of policy and research in the areas of BoP and competitiveness due to their central role in global supply chain clusters. MNEs, on the other hand, are also recognizing these developing and emerging economies as their potential target markets. Managers are concerned to align business strategies of MNEs with aspiration of policy makers in host market for effective expansion in these markets. Partnering with local firm through supply chain clusters in host markets is being seen as a useful strategic tool to enhance local embeddedness and internationalization in developing and Least Developing Countries (LDCs) markets (Meyer, Mudambi and Narula, 2011).

Pakistan like other developing Asian economies is also facing the problems of poverty, social exclusion and lack of competitiveness of firm sector (HafeezSiddiqui et al, 2010; OECD \&UNCTAD, 2013). The United Nations Conference on Trade and Development (UNCTAD) has also stressed the need for making economic growth more inclusive in its latest Least Developed Countries (LDCs) Report (2013). The report emphasizes the need for the 49 poorest countries in the world to make greater efforts to ensure that economic growth can help their poor. Many countries in Asia, such as Bhutan, Bangladesh and Afghanistan are also categorized as LDCs. Countries like Pakistan are, however, not far ahead and face very similar challenges in terms of achieving growth which can offer better opportunities to its deprived populace. With population of 180 million and vast natural resources, the country is seen as a potential target market by MNEs. State Bank of Pakistan (2012) in its annual report has also pointed to the need for inclusive growth policies enabling entrepreneurship and jobs at lower ends of the economy.

There is need of informed recommendations based on rigorous research about how effective alignment of firms at BoP with supply chain clusters of MNEs operating in Pakistan is expected to bring mutual fruits to both partners. There are some important studies regarding the engagement of MNEs in Pakistan with inclusive entrepreneurship and social development. Gold et al (2013) has given the example of Nestle Pakistan for creating shared value by engaging poor dairy farmers mostly women in its supply chain strategy. Sodhi and Tang (2016) have explained the role of micro and small firms in the BoP supply chain network with MNEs and other large firms. Present study takes its roots from the network theory of internationalization which explains the relationship between network membership and internationalization performance/strategy (Camison and Villar, 2009; Elg et al, 2008; Johanson and Vahlne, 20019; Johanson et al, 2012; Hosseini and Dadfar, 2012; Ngoma and Ntale, 2014). While this 
and other such studies point to the possible scope of MNE activity with respect to their pro-business contribution to BoP market in host markets yet the impact of supply chain linkages on MNEs' internationalization performance is yet to be explained theoretically and with generalizable empirical evidence from Pakistan.Market knowledge competence has been a vital factor in driving internationalization of MNEs in host markets specially with respect to network relationships and considerable developments have been made to operationalize it (Torkkeli 2013; Petersen, 2003; Barbosa et al, 2014; Bhatti et al, 2016, Casillas, 2015; Hohenthal et al, 2014; Ozkaya et al, 2015). However, there is need to link the construct of market knowledge competence to supply chain network linkages in BoP market.

Present study looks into the theoretical foundations of 'doing well by doing good' concept and examines the influence of BoP supply chain cluster linkages on MNEs competitiveness and internationalization strategy. The current study proposes model of engaging BoP firms into supply chain cluster by MNEs, as an exogenous variable, and relates it with their internationalization strategy in host markets with mediating role of market knowledge competence.

Furthermore, this study is aimed to gather empirical data:

- To test the validity of latent constructs to measure study variables that hypothesize role of BoP supply chain cluster linkages on sustainable internationalization of MNEs in host market;

- To test validity and reliability of items used to measure various latent variables to ascertain the internal consistency.

Findings of the study will lead to development of valid and reliable measurement constructs to analyze the sustainability of MNE activity in host markets in terms of their relationship with BoP firms through supply chain linkages.
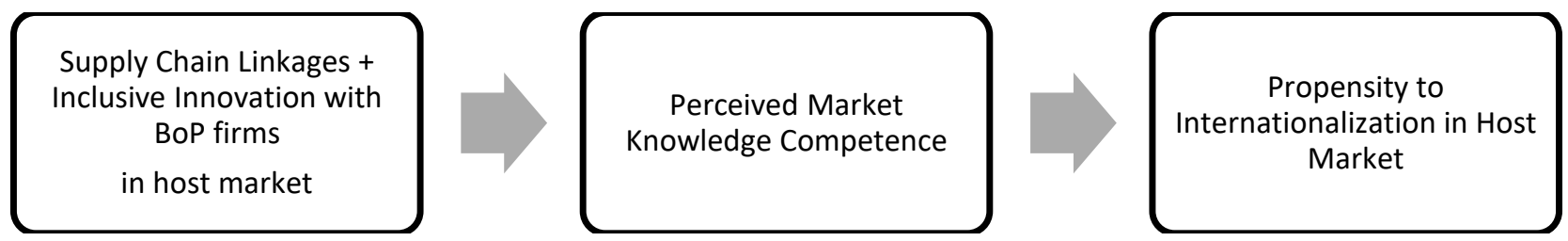

Figure 1 Relationship between BoP Supply Chain Network and MNEs’ Internationalization

\subsection{Research Methodology}

The proposed model of study depicts a causal relationship between BoP supply chain linkages and propensity to internationalization along with mediating role of perceived market knowledge competence. An exploratory research design is used. The pilot test is a technique to pre-test the validity of latent constructs of proposed model of study and testing reliability of survey instrument before collecting actual data. It is a technique to measure the research variables from the sample to achieve the objectives of the studies.Pilot study is the quality control mechanism of research design to assess the validity and reliability of the data collection instrument. According to Gay, Mills \&Airasian (2006), it involves a small scale study to analyze the measurement model and data collection instrument before going for the full-fledged study.Pilot study is the quality control mechanism of research design to assess the validity and reliability of the data collection instrument. The sample size for pilot studies can be comparatively 
smaller ranging from 30-40 respondents with better results to be expected as the sample size may increase. The present pilot study is conducted via 50managerial level employees in the supply chain and marketing department of subsidiaries of foreign MNEs in food and beverages sector of Pakistan. Sample was taken from companies which have employed certain level of supply chain linkages with BoP enterprises in Pakistan. Data has been collected using structured questionnaire.

\subsection{Measurement, Questionnaire Design and Data Collection Method}

Table 1 mentions key variables of the study and their relationship direction taken from the proposed model depicting relationship between BoP supply chain linkages and MNEs propensity to internationalization. The list of latent variables and their corresponding measures related to hypothesized relationship has been mentioned in table 2 . The indicators used to measure the latent constructs have been adapted from the previous studies mentioned in table 2 and the pre-test procedures to incorporate experts' opinion. The multiple-indicator concept has been used in the designing of structured questionnaire whichwas administered through in person and mall intercept survey. Purpose of using multiple indicators has been to get reliable results on the latent variables that cannot be observed directly. Five-point likert scale was used to measure the indicators of research variables. The indicators have been selected based on their validity and reliability scores in the previous studies and on the basis of pilot study results. The nominal scale has been used to measure demographic characteristics of the managers. Structured questionnaire as data collection instrument was administered on a representative sampleto obtain data and test the validity and reliability of latent constructs and their indicators (Bryman and Bell, 2015).

Table $1 \quad$ Variables of the study and their classification

\begin{tabular}{|c|c|}
\hline $\begin{array}{l}\text { Independent } \\
\text { Variables }\end{array}$ & $\begin{array}{c}\text { - Inclusive supply chain linkages with BoP firms } \\
\text { - } \quad \text { Upstream linkages } \\
\text { - } \quad \text { Downstream linkages } \\
\text { - Inclusive innovation in supply chain linkages }\end{array}$ \\
\hline Mediating Variable & - Perceived market knowledge competence \\
\hline Dependent Variable & - Propensity to internationalization \\
\hline Control Variables & $\begin{array}{ll}\text { - } & \text { Manager's position } \\
\text { - } & \text { Manager's education } \\
\text { - } & \text { Manager's training programs attended }\end{array}$ \\
\hline
\end{tabular}

\subsubsection{Validity and Reliability of Items and Scales}

Once the tentative questionnaireconstructed, the next vital step was to look into the validity and reliability of items used to measure various latent variables in the data collection instrument. While external validity of results i.e. generalizability is best ensured by sampling strategy, the internal validity corresponds to the truthfulness of the items to represent variable. This is also referred to as task of establishing goodness of measures. Validity refers to whether the item or construct used to measure a variable is measuring it correctly or not (Babbie, 2013). According to Sekaran (2016), the measurement 
Table 2 List of variables and their indicators

\begin{tabular}{|c|c|c|c|}
\hline Main Variable & Sub variable & Indicators & Source \\
\hline $\begin{array}{l}\text { Inclusive Supply } \\
\text { chain Linkages }\end{array}$ & \multicolumn{2}{|c|}{$\begin{array}{l}\text { - Supply chain linkages with BoP suppliers } \\
\text { - Supply chain linkages with BoP resellers } \\
\text { - Supply chain linkages with other BoP services providers }\end{array}$} & Sodhi\& Tang, 2016 \\
\hline & $\begin{array}{l}\text { Cooperation with } \\
\text { BoP Suppliers }\end{array}$ & $\begin{array}{l}\text { - Exchange of information and experience } \\
\text { - Negotiation of payment and delivery } \\
\text { - Joint marketing }\end{array}$ & $\begin{array}{l}\text { Kongmanila\& } \\
\text { Takahashi, } 2009\end{array}$ \\
\hline
\end{tabular}

scales used to measure items can be imperfect and thereby may lead to errors. 


\begin{tabular}{|c|c|c|c|}
\hline \multirow{4}{*}{$\begin{array}{l}\text { Dimensions of } \\
\text { Inclusive Supply chain } \\
\text { Linkages }\end{array}$} & & - Training participation & \\
\hline & $\begin{array}{l}\text { Cooperation with } \\
\text { BoP } \\
\text { subcontractors }\end{array}$ & $\begin{array}{l}\text { - Exchange of information and experience } \\
\text { - Negotiation of payment and delivery } \\
\text { - Joint marketing } \\
\text { - Training participation } \\
\end{array}$ & $\begin{array}{l}\text { Kongmanila\& } \\
\text { Takahashi, } 2009\end{array}$ \\
\hline & $\begin{array}{l}\text { Cooperation with } \\
\text { BoP Resellers }\end{array}$ & $\begin{array}{l}\text { - Exchange of information and experience } \\
\text { - Negotiation of payment and delivery } \\
\text { - Joint marketing } \\
\text { - Training participation }\end{array}$ & $\begin{array}{l}\text { Kongmanila\& } \\
\text { Takahashi, } 2009\end{array}$ \\
\hline & $\begin{array}{l}\text { Cooperation with } \\
\text { other BoP firms }\end{array}$ & $\begin{array}{l}\text { - Exchange of information and experience } \\
\text { - Negotiation of payment and delivery } \\
\text { - Joint marketing } \\
\text { - Training participation }\end{array}$ & $\begin{array}{l}\text { Kongmanila\& } \\
\text { Takahashi, } 2009\end{array}$ \\
\hline & $\begin{array}{l}\text { Cooperation with } \\
\text { BoPsubcontractors }\end{array}$ & $\begin{array}{l}\text { - Exchange of information and experience } \\
\text { - Negotiation of payment and delivery } \\
\text { - Joint marketing } \\
\text { - Training participation } \\
\end{array}$ & $\begin{array}{l}\text { Kongmanila\& } \\
\text { Takahashi, } 2009\end{array}$ \\
\hline Inclusive Innovation & \multicolumn{2}{|c|}{$\begin{array}{l}\text { - Innovation relevant for BoP firms } \\
\text { - Innovation that involves BoP firms } \\
\text { - Innovation that benefits BoP firms }\end{array}$} & Foster \&Heeks, 2013 \\
\hline $\begin{array}{l}\text { Perceived Market } \\
\text { Knowledge } \\
\text { Competence }\end{array}$ & \multicolumn{2}{|c|}{$\begin{array}{l}\text { - Knowledge about customers } \\
\text { - Knowledge about competitors } \\
\text { - Knowledge about local market environment } \\
\text { - Knowledge about supply chain activities } \\
\text { - Adaptation of information and communication system to } \\
\text { integrate with BoP allies } \\
\text { - Alliance learning }\end{array}$} & $\begin{array}{l}\text { Ozkaya et al, 2015; } \\
\text { Barbosa et al, 2014; } \\
\text { Bhatti et al, 2016, } \\
\text { Casillas, 2015; } \\
\text { Hohenthal et al, } 2014\end{array}$ \\
\hline $\begin{array}{l}\text { Propensity to } \\
\text { Internationalization }\end{array}$ & \multicolumn{2}{|c|}{$\begin{array}{l}\text { - Likelihood of increase in sales } \\
\text { - Possibility of increase in sales } \\
\text { - Likelihood of increase in jobs } \\
\text { - Possibility of increase in jobs } \\
\text { - Likelihood of increase in commercial presence } \\
\text { - Possibility of increase in commercial presence }\end{array}$} & $\begin{array}{l}\text { Pauwels et al., } 2009 \\
\text { Somer, 2009. Akhter } \\
\text { and Robels, } 2006\end{array}$ \\
\hline Control Variables & \multicolumn{2}{|c|}{$\begin{array}{l}\text { - } \text { Manager's age } \\
\text { - Manager's Qualification } \\
\text { - Training programs attended }\end{array}$} & $\begin{array}{l}\text { Sousa \&Lages, 2010; } \\
\text { Kongmanila\& } \\
\text { Takahashi, } 2009\end{array}$ \\
\hline
\end{tabular}

In present study, the items used to measure latent constructs of propensity to internationalization, perceived market knowledge, inclusive innovation, inclusive supply chain linkages and its variants backward, forward and horizontal have been pilot tested before starting the actual field work.

During the pilot testing phase of the study, exploratory factor analysis along with other measures of reliability and validity were run to identify the valid and reliable items to be included in the proposed model. The expert opinion of experienced supply chain managers was also sought during the pilot testing in order to determine the need for additional items or identify week items.

\subsection{Results}

PLS software was used to runexploratory factor analysis (EFA) and other tests of validity and reliability to identify the valid constructs and the most valid and reliable items of each variable in the model. Since the proposed model of study consists of reflective measures for all dimensions, the internal consistency measured by reliability coefficient like Cronbach's alpha and other statistical measures for the reliability 
are to be calculated for these constructs. According to Jarvis, MacKenzie\&Podsakoff (2003), these tests screen items which are consistent and measuring the same phenomenon. The Cronbach's alpha reliability coefficients were calculated for all measures. In overall terms, the pilot test attempted to ensure that the instrument to be used remains valid and reliable and also that it remains free of any measurement error.

\subsubsection{Reliability Test}

Reliability tests evaluate the level of consistency among several measurements which measure a given construct (Hair et al., 2010). Thevalue of Cronbach's alpha coefficient reflects the items'internal consistency or reliability. A higher value obtained indicates higher consistency and thereby better ability of the items to measure the intended construct.

Table 3.4 presents the Cronbach's alpha coefficient for all the constructs used in this study. It can be seen that almost all Cronbach's alpha values are more than 0.6. According to Hair et al. (2010), the minimum acceptable limit is 0.6. Only for the construct 'Subcontractor Linkages', the Cronbach's alpha coefficient is very low i.e. -0.150. This construct was also found low on the factor loading score representing low validity of its items. As a result this construct was deleted. This construct used to measure horizontal supply chain linkages between MNE and BoP firms along with the other another construct to measure the same. During the pre-test also, the experts opined that it is difficult to comprehend the difference between the construct 'linkage with other BoP firms' and linkages with BoP subcontractors' and suggested to delete one of those to make the construct more comprehendible. All other items included in the instrument reflected an adequate level of internal consistency associated with their respective measures.

\subsubsection{Construct Validity}

According to Churchill (1979) and Sekaran (2016), possessing an appropriate level of reliability score does not necessarily imply goodness of measurement represented by validity of the construct items. Validity of a construct refers to the the extent to which the items measure what they are actually intended to measure (Nunnally\& Bernstein, 1994). Content and construct validity measures are considered to be the most frequently used measures. Content validity by experts is mostly a judgmental assessment of the items, constructs, and instrument as a whole which have been developed and based on extensive literature. On the other hand, construct validity is performed to ascertain that a test is evaluating the construct it was actually supposed to.

Furthermore, construct validity is considered important to ensure overall validity. In order to evaluate the construct validity, factor analysis was conducted in this study using PLS. The objective of the factor analysis is to screen the items explaining same construct. All construct items and their factor loading were found sufficiently higher except for subcontractor linkages and therefore removes form the measurement model. Final measurement model and data collection instrument was designed based on the results of pilot study mentioned in table 3 .

The proposed measurement model based on the results of the study has been depicted in figure 2 . The model explains the structural relationship between supply chain linkages with BoP firms and propensity to internationalization of MNEs in host market. The model is augmented with the measurement indicators of each latent construct and the results of analysis obtained from the study. 
Table 3 Constructs and Items: Measures of Reliability and Validity

\begin{tabular}{|c|c|c|c|c|}
\hline Construct and Items & $\begin{array}{l}\text { Factor } \\
\text { loading }\end{array}$ & $\begin{array}{c}\text { Cronbach's } \\
\text { Alpha }\end{array}$ & $\begin{array}{c}\text { Average } \\
\text { Variance } \\
\text { Extracted }\end{array}$ & $\begin{array}{c}\text { Items } \\
\text { Deleted }\end{array}$ \\
\hline Propensity to Internationalization & & 0.849 & 0.573 & Nil \\
\hline ITZ1 Likelihood of increase in sales & 0.850 & & & \\
\hline ITZ2 Possibility of increase in sales & 0.612 & & & \\
\hline ITZ3 Likelihood of increase in jobs & 0.783 & & & \\
\hline ITZ4 Possibility of increase in jobs & 0.710 & & & \\
\hline ITZ5 Likelihood of increase in commercial presence & 0.813 & & & \\
\hline ITZ6 Possibility of increase in commercial presence & 0.750 & & & \\
\hline Market Knowledge Competence & & 0.811 & 0.515 & Nil \\
\hline MK1 Knowledge about customers & 0.782 & & & \\
\hline MK2 Knowledge about competitors & 0.751 & & & \\
\hline MK3 Knowledge about local market environment & 0.703 & & & \\
\hline MK4 Knowledge about supply chain activities & 0.776 & & & \\
\hline MK5 communication system to integrate with BoP & 0.633 & & & \\
\hline MK6 Alliance learning in BoP supply chain linkages & 0.647 & & & \\
\hline Inclusive Supply chain Linkages with BoP & & 0.708 & 0.635 & Nil \\
\hline IS1 Supply chain linkages with BoP suppliers & 0.870 & & & \\
\hline IS2 Supply chain linkages with BoP resellers & 0.720 & & & \\
\hline IS3 Supply chain linkages with other BoP firms & 0.793 & & & \\
\hline Inclusive Innovation in BoP Supply Chain Cluster & & 0.861 & 0.782 & Nil \\
\hline II1 Innovation relevant for BoP firms & 0.883 & & & \\
\hline II2 Innovation that involves BoP firms & 0.885 & & & \\
\hline II3 Innovation that benefits BoP firms & 0.886 & & & \\
\hline Forward Linkages with BoP firms & & 0.755 & 0.577 & Nil \\
\hline FL1 Exchange of information and experience & 0.822 & & & \\
\hline FL2 Negotiation of payment and delivery & 0.719 & & & \\
\hline FL3 Joint marketing & 0.750 & & & \\
\hline FL4 Training participation & 0.743 & & & \\
\hline Horizontal Linkages with BoP firms & & 0.743 & 0.562 & Nil \\
\hline HL1 Exchange of information and experience & 0.819 & & & \\
\hline HL2 Negotiation of payment and delivery & 0.756 & & & \\
\hline HL3 Joint marketing & 0.711 & & & \\
\hline HL4 Training participation & 0.706 & & & \\
\hline Subcontractor Linkages with BoP firms & & -0.150 & 0.294 & Removed \\
\hline SL1 Exchange of information and experience & 0.110 & & & \\
\hline SL2 Negotiation of payment and delivery & 0.885 & & & \\
\hline SL3 Joint marketing & -0.293 & & & \\
\hline SL4 Training participation & 0.213 & & & \\
\hline Backward Linkages with BoP firms & & 0.863 & 0.787 & Nil \\
\hline BL1 Exchange of information and experience & 0.868 & & & \\
\hline BL2 Negotiation of payment and delivery & 0.776 & & & \\
\hline BL3 Joint marketing & 0.855 & & & \\
\hline BL4 Training participation & 0.863 & & & \\
\hline
\end{tabular}




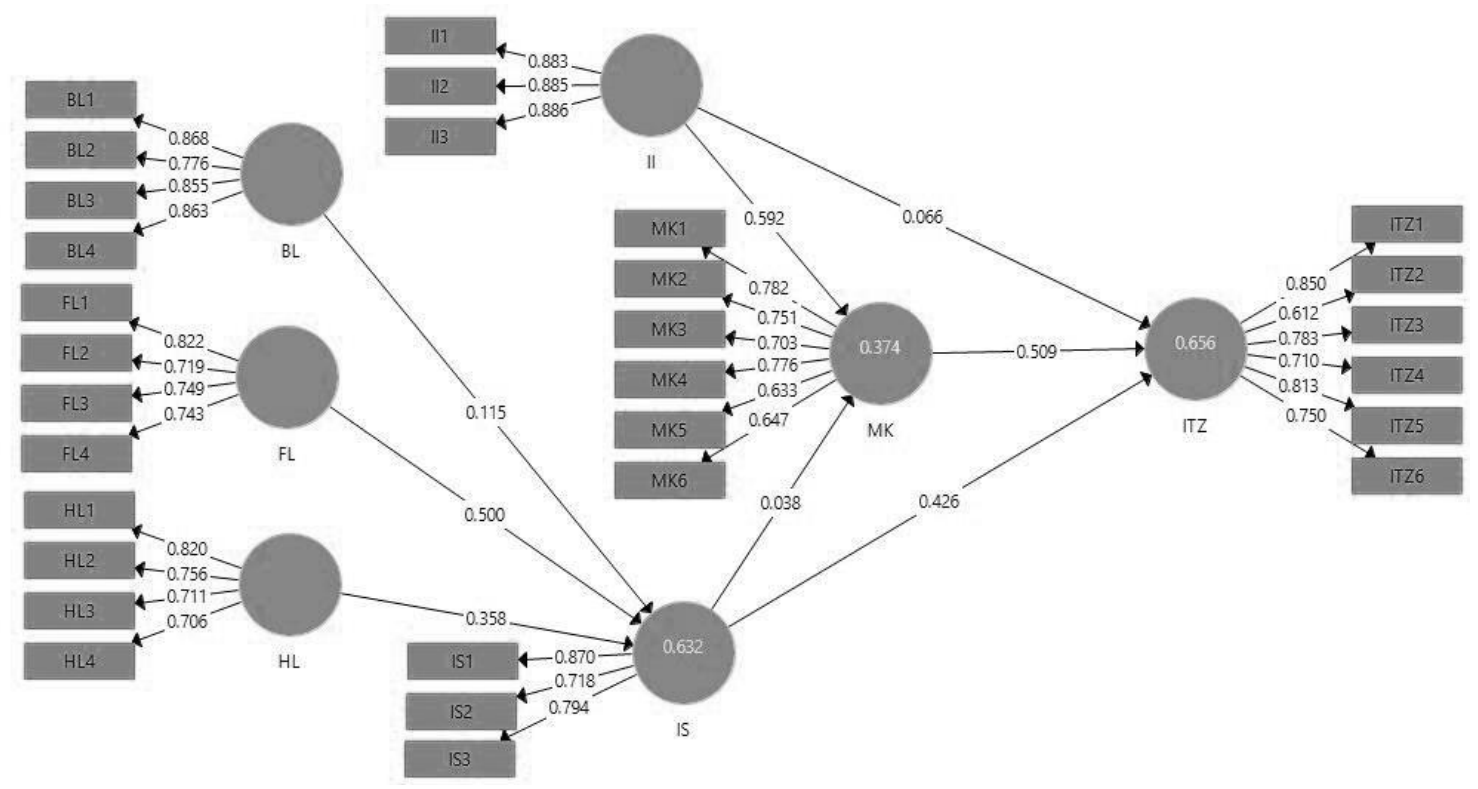

Figure 2: $\quad$ Variables and Relationships in Proposed Model of Sustainable Internationalization after DataReduction

\subsection{Conclusion}

This paperdescribes the theoretical framework and measurement model to analyze the relationship between supply chain linkages with BoP firms in host market and MNEs internationalization strategy. The model postulates perceived market knowledge competence as the mediating variable in the relationship between BoP supply chain linkages with micro and small firms in host market and MNEs internationalization strategy in host market. The reliability and validity of latent variables and their indicators has been examined to refine the measurement model and questionnaire tool for further surveying. In addition to the practical implications for MNEs strategies in developing host markets, the findings of the study will be useful for furtherquantitiave studies in the area of firms' internationalization especially in relations to their supply chain linkages with local firms in host market.

\section{References}

Akhter, S. H., \& Robles, F. (2006). Leveraging internal competency and managing environmental uncertainty: Propensity to collaborate in international markets. International Marketing Review, 23(1), 98-115.

Andersen, P. H. (2011). Imagining and Realizing Network-Based Business Models for BOP Markets: The Case of Grundfos LIFELINK. In Proceedings of the 2011 27th IMP Conference, Glasgow, UK (pp. 1-3).

Babbie, E. R. (2013). The basics of social research. Cengage Learning.

Barbosa, S. L., Rezende, S. F. L., \&Versiani, A. F. (2014).Relationships and knowledge in the firm internationalization process. Revista de Administração (São Paulo), 49(1), 129-140.

Bhatti, W. A., Larimo, J., \&Coudounaris, D. N. (2016).The effect of experiential learning on subsidiary knowledge and performance. Journal of Business Research, 69(5), 1567-1571.

Camisón, C., \&Villar, A. (2009).Capabilities and propensity for cooperative internationalization. International Marketing Review, 26(2), 124-150.

Casillas, J. C., Barbero, J. L., \& Sapienza, H. J. (2015).Knowledge acquisition, learning, and the initial 
pace of internationalization. International Business Review, 24(1), 102-114.

Chataway, J., Hanlin, R., \&Kaplinsky, R. (2014). Inclusive innovation: an architecture for policy development. Innovation and Development, 4(1), 33-54.

Churchill Jr, G. A. (1979). A paradigm for developing better measures of marketing constructs. Journal of marketing research, 64-73.

De Soto, H. (2000). The mystery of capital: Why capitalism triumphs in the West and fails everywhere else. Basic Civitas Books.

Elg, U., Ghauri, P. N., \&Tarnovskaya, V. (2008). The role of networks and matching in market entry to emerging retail markets. International Marketing Review, 25(6), 674-699.

Foster, C., \&Heeks, R. (2013). Conceptualising inclusive innovation: Modifying systems of innovation frameworks to understand diffusion of new technology to low-income consumers. The European Journal of Development Research, 25(3), 333-355.

Gay, L. R., Mills, G. E., \&Airasian, P. (2006). Educational research: Competencies for analysis and research.

Gold, S., Hahn, R., \&Seuring, S. (2013). Sustainable supply chain management in "Base of the Pyramid" food projects-A path to triple bottom line approaches for multinationals?. International Business Review, 22(5), 784-799.

Gold, S., Hahn, R., \&Seuring, S. (2013). Sustainable supply chain management in "Base of the Pyramid" food projects-A path to triple bottom line approaches for multinationals?. International Business Review, 22(5), 784-799.

Hafeez Siddiqui, S., \&Mujtaba Nawaz Saleem, H. (2010).Services-led industrial policy for inclusive growth and competitiveness. Competitiveness Review: An International Business Journal, 20(2), 166-181.

Hair, J. F., Black, W. C., \&Babin, B. J. (2010). RE Anderson Multivariate data analysis: A global perspective.

Hohenthal, J., Johanson, J., \&Johanson, M. (2014).Network knowledge and business-relationship value in the foreign market. International Business Review, 23(1), 4-19.

Hosseini, M., \&Dadfar, H. (2012). Network-based theories and internationalization of firms: applications to empirical studies. The Business \& Management Review, 3(1), 182.

Jarvis, C. B., MacKenzie, S. B., \&Podsakoff, P. M. (2003).A critical review of construct indicators and measurement model misspecification in marketing and consumer research. Journal of consumer research, 30(2), 199-218.

Johanson, J., \&Vahlne, J. E. (2009). The Uppsala internationalization process model revisited: From liability of foreignness to liability of outsidership. Journal of international business studies, 40(9), 1411-1431.

Johanson, M., \& Kao Tsung, P. (2012). Network and internationalisation: A Review of more than 20 Years of Research. In 28th IMP conference; Combining the social and technological aspects of innovation: relationships and networks; 11th-15th September 2012; Rome, Italy.

Kolk, A., Rivera-Santos, M., \&Rufín, C. (2014). Reviewing a Decade of Research on the "Base/Bottom of the Pyramid"(BOP) Concept. Business \& Society, 53(3), 338-377.

Kongmanila, X., \& Takahashi, Y. (2009). Inter-firm cooperation and firm performance: An empirical study of the Lao garment industry cluster. International Journal of Business and Management, 4(5), 3.

Meyer, K. E., Mudambi, R., \&Narula, R. (2011). Multinational enterprises and local contexts: the opportunities and challenges of multiple embeddedness.Journal of Management Studies, 48(2), 235-252.

Ngoma, M., \&Ntale, P. D. (2014).Network competence and internationalization of service firms in Uganda. Asian Journal of Science and Technology, 5(3), 160-170.

Nunnally, J. 
OECD and UNCTAD (2013) Implications of Global Value Chains for Trade, Investment and Development and Jobs. Prepared for the G-20 Leaders Summit, Russia, 20.

Oosterlaken, I. (2009). Design for development: A capability approach. Design issues, 25(4), 91-102.

Ozkaya, H. E., Droge, C., Hult, G. T. M., Calantone, R., \&Ozkaya, E. (2015).Market orientation, knowledge competence, and innovation. International Journal of Research in Marketing, 32(3), 309-318.

Pauwels, P. F. J., Patterson, P. G., de Ruyter, K., \&Wetzels, M. (2003). The propensity to continue service internationalization: a model of planned behavior.

Petersen, B., Pedersen, T., \& Sharma, D. D. (2003). The role of knowledge in firms' internationalisation process: Wherefrom and whereto. Learning in the internationalisation process of firms, 36-55

Prahlad, C. K., \& Hart, S. L. (2002). The Fortune at the Bottom of the Pyramid" e-Doc. Staregy+ Business, (26).

Sekaran, U., \&Bougie, R. (2016). Research methods for business: A skill building approach. John Wiley $\&$ Sons.

Sinkovics, N., Sinkovics, R. R., \&Yamin, M. (2014). The role of social value creation in business model formulation at the bottom of the pyramid-implications for MNEs?. International Business Review, 23(4), 692-707.

Sodhi, M. S., \& Tang, C. S. (2016). Supply chain opportunities at the bottom of the pyramid. Decision, 43(2), 125-134.

Soete, L. (2014). Research and Innovation for Sustainable Development.In Technologies for Sustainable Development (pp. 239-244).Springer, Cham.

Sousa, C. M., \& Filipe Lages, L. (2011). The PD scale: a measure of psychic distance and its impact on international marketing strategy. International Marketing Review, 28(2), 201-222.

Torkkeli, L. (2013). The Influence of Network Competence on Internationalization of SMEs. ActaUniversitatisLappeenrantaensis. 